\title{
Restoration after bush control in selected range- land areas of semi-arid savannas in South Africa
}

\author{
Authors \\ ${ }^{1}$ Klaus Kellner (1) \\ ${ }^{1}$ Reletile T. Mangani (D) \\ Tshegofatso J.K. Sebitloane (1) \\ 2Johannes G. Chirima (B) \\ ${ }^{1}$ Nadine Meyer (1) \\ ${ }^{1}$ Hendri C. Coetzee $\mathbb{C}$ \\ Pieter W. Malan (1) \\ 'Jaco Koch (1D)

\section{Affiliations} \\ ${ }^{1}$ Unit for Environmental Sciences \\ and Management, North-West \\ University, Private Bag X6001, \\ Potchefstroom 2520, South \\ Africa. \\ ${ }^{2}$ ARC-Institute for Soil, Climate and \\ Water, Geo-Information Science \\ Division, Private Bag X79, \\ Pretoria, 0001, South Africa.

\section{Corresponding Author} \\ Prof. Klaus Kelner, \\ Klaus.Kellner@nwu.ac.za
}

\section{Dates}

Submitted: 23 October 2019

Accepted: 30 April 2020

Published: 24 February 2021

\section{How to cite this article:}

Kellner, K., Mangani, R.T., Sebiloane, T.J.K., Chirima, J.G., Meyer, N., Coetzee, H.C., Malan, P.W. \& Koch, J., 2021, 'Restoration after bush control in selected rangeland areas of semi-arid savannas in South Africa', Bothalia 51(1), a7. http://dx.doi. org/10.38201/btha.abc.v51.i1.7
Background: One of the main causes of land degradation in South Africa is bush thickening (BT) of mainly Senegalia or Vachellia species. Restoration methods are required to control $\mathrm{BT}$, and to improve grass biomass production and soil conditions in South Africa.

Objectives: The objectives of this study were to determine the effect of brush packing (BP) as a restoration method to increase grass biomass production, assess soil moisture after BP on different soil types, and document the perceptions of the local communities towards BP.

Method: Methods included cutting the stems of woodies with a diameter of at least $10 \mathrm{~cm}$ at knee height by chainsaw and manual clipping after which an arborocide was applied to the stumps. A neutron probe was used to measure volumetric moisture content at two different soil depths. The grass biomass was analysed using ANOVA at a confidence level of 95\%. Quantitative and qualitative approaches were used to gather information about the perceptions of local communities towards restoration in group discussions.

Results: The short-term data showed that the implementation of BP as restoration method increased grass biomass production. The soil texture influenced the volumetric soil moisture. Higher soil moisture content was found in the deeper clayey soils. The local participants' interpretation towards the restoration project was positive.

Conclusion: The project increased the grazing potential and contributed to job creation to improve the well-being of the people in the community.

Key words: biomass production, degraded lands, bush thickening, brush packing, land users' perceptions.

\section{Introduction}

The degradation of rangelands in the arid and semi-arid areas of the world, and especially in southern Africa, is increasing at alarming rates, mainly due to land mismanagement, untenable land-tenure systems and climate change (Hoffman \& Ashwell 2001). Human-induced degradation by management and land tenure types often leads to changes in the species composition (Siebert et al. 2021). Land degradation threatens livestock and game production that depends on the natural ecosystem for forage production while it also has a negative impact on ecosystem services (ES) such as the provision of potable water and food (Havstad et al. 2007; Schwilch, Hessel \& Verzandvoort 2012). These basic ecosystem services are important and can be maintained by implementing sustainable land-management (SLM) practices (Liniger \& Studer, 2019). At the Rio Earth Summit in 1992, SLM was defined as the viable use of resources, including soils, water, animals and plants for the production of goods and services to meet changing human needs, while simultaneously ensuring the 
long-term productive potential of these resources and the maintenance of environmental functions'.

The rain-fed arid- and semi-arid regions in southern Africa are characterised by variable, often unpredictable, rainfall events (in-space, inter-annually and intra-seasonally), leading to unexpected droughts (Kellner et al. 2018). The resultant degradation of water resources and the deterioration of the condition of soil and vegetation have a negative impact on the sustainability of land and ecosystem services. However, well applied SLM practices can conserve and protect the multiple services and functions provided by the land (Von Maltitz, Lindeque \& Kellner, 2018).

Land degradation is often associated with overgrazing and the concomitant negative impacts on ES (Swift, Izac \& Van Noordwijk 2004). Nevertheless, Shackleton et al. (2008) caution that understanding the complexity between climate change and management applications that leads to land degradation requires careful investigation.

Different land-tenure regimes are found in southern Africa, that have different impacts and extents on land degradation, including the increase in the density of woody species (also called woody or bush thickening - BT), which affects the ES (Von Maltitz, Lindeque \& Kellner, 2018; Von Maltitz et al., 2019). Broadly, these tenure systems resort under one of three main categories: (1) private and leasehold land, also referred to as 'commercially managed areas'; (2) communal land, which is mainly traditional-owned land managed by local authorities, including some form of commercial management; and (3) conservation areas (private and state-owned).

An assessment of land degradation in drylands found that communal-managed areas are highly degraded with a loss in productivity and biodiversity, associated with increased soil erosion (Liniger \& Studer 2019; Petri, Biancalani \& Lindeque 2019). An underlying cause of this degradation in the sustainability of drylands is bush thickening.

\section{Bush thickening}

Using aerial photographs dated from 1940 to 2010, Buitenwerf et al. (2012) found that woody cover had doubled in commercial, communal and conservation rangeland areas. Skowno et al. (2017) found that only 2.7 million ha had been affected by BT between 1990 and 2013, but recent findings by Turpie et al. (2018) suggest that BT ranges from 5.7 to 13 million ha in South Africa.

Savanna, South Africa's most prominent biome, is used extensively as rangeland for the production and conservation of livestock and/or wildlife, as well as subsistence crop farming (Kgosikoma, Harvie \& Mojeremane 2012; Liniger \& Studer 2019). The vegetation structure and composition of these savannas vary considerably due to variances in topography, soil and climate (Mucina \& Rutherford 2006). Large parts of the savannas in the more arid- and semi-arid regions towards the west and north of the country are degraded due to the densification of alien and indigenous woody shrub and tree species, resulting in so-called 'bush thickening' (BT) (Joubert, Rothauge \& Smit 2008). In these areas, the Savanna Biome is dominated by Senegalia mellifera (Vahl) Seigel \& Ebinger and/or Vachellia species, including other woody and some herbaceous species.

Bush encroachment, however, refers to instances where woody species (shrubs and trees) establish in areas where they did not previously occur (De Klerk 2004; Smit, Richter \& Aucamp 1999). Bush thickening (BT) is caused by a dynamic change in vegetation composition, structure and density over time (De Klerk 2004; Smit, Richter \& Aucamp 1999). Bush thickening is caused by established stands of woody species, which increase in density and cover mostly as a result of fire and grazing management, below-average rainfall, competition between $\mathrm{C}_{3}$ and $\mathrm{C}_{4}$ type plants and elevated $\mathrm{CO}_{2}$ levels (Buitenwerf et al. 2012; Dreber, Van Rooyen \& Kellner 2018; Higgins, Bond \& Trollope 2007; Kellner 2008; Kraaij \& Ward 2006; Ward 2005).

Due to the imbalance in the grass-woody ratio and the loss of grass cover, especially palatable forage species, BT causes a decline in the functionality of savanna rangelands (Britz \& Ward 2007; Eldridge et al. 2011; Harmse, Kellner \& Dreber 2016). Furthermore, the decrease in grass densities reduces the soil's infiltration rate and increases raindrop impact, ultimately increasing surface runoff and soil erosion (Donahue \& Auburn 2003). According to Gregory et al. (2015), each soil type will respond differently to a lack of cover due to its properties. Clayey soils are more prone to compaction due to cohesion, while a sandy soil is more prone to structure loss leading to erosion by wind or water. Bush thickening also has significant socio-ecological implications for land users since the resultant degradation decreases the value of the land for grazing and livestock keeping, as well as for game viewing and eco-tourism (De Klerk 2004; Arbieu et al. 2017).

To control BT and compensate for economic losses, land users apply active or passive restoration methods (Wigley, Bond \& Hoffman 2009). Although sound rangeland management practices can reduce BT, local capacity and knowledge to enforce control/clearing measures are often lacking. The type of bush-clearing technology employed, whether chemical, manual, mechanical or a combination thereof, must be determined by the density and type of woody species causing the thickening or encroachment (Barac, Kellner \& De Klerk 2004; De Klerk 2004). Clearing thickened bush normally 
increases biomass production of grasses, depending on the soil type and rainfall pattern, as well as the technology implemented. Bush clearing and the eradication of alien species can lead to economically feasible enterprises such as the production of charcoal, animal feed, timber for construction purposes and wood for cooking and heating. Establishing enterprises such as these could also result in job creation (Sudha et al. 2003; De Klerk 2004; Rothauge \& Gschewender 2014).

\section{Restoration}

The Society for Ecological Restoration (2004) defines ecological restoration as the process of assisting the recovery of an ecosystem that has been degraded, damaged or destroyed. Re-seeding methods of palatable, perennial grasses is often applied in restoration at a small scale, especially when the soil seed bank is depleted (Kellner 2008).

In South Africa, the Natural Resource Management Unit, resorting under the Department of Environment, Forestry and Fisheries (DEFF), is responsible for the restoration of degraded lands, with the inclusion of related research and development projects (Van Wilgen et al. 2001). In addition, the Land Care Programme resorting under the Department of Agriculture, Land Reform and Rural Development is also involved in controlling bush thickening (BT) and implementing SLM practices (Mulder \& Brent 2006). One of the approaches for the restoration of rangelands after bush clearing, that is supported by these departments, is brush packing (BP).

BP entails covering the soil surface with organic material such as woody branches and leaves of plants to promote grass growth and biomass production (Visser et al. 2007; Kellner 2008). BP also protects seedlings from disturbances (defoliation and trampling) and modify microclimate to make conditions (such as moisture content, soil structure and temperature and nutrient content) suitable for germination and establishment (Tongway \& Ludwig 2011; Modungwa 2017). If branches and roots from plants with nitrogen fixing abilities (e.g. Vachellia and Senegalia species) are used, the decomposing brush will not only enrich the nutrient component of the soil and increase the functionality of the vegetation that established under the woody twigs, but will also help to control erosion (Modungwa 2017).

Although labour intensive, BP is a cost-effective restoration method since no fenced paddocks nor rotational grazing is required to protect/rest the land. Due to its labour-intensive nature, clearing invasive woody species also provides job opportunities for local people, thereby contributing to the well-being of the affected communities.

This study sets out to compare different restoration methods involving BP after bush clearing. The specific objectives of the study were to determine (i) the effect of $\mathrm{BP}$ and re-seeding on the grass biomass production following bush control; (ii) measure changes in moisture flux with soil depth after the application of BP at selected study areas representing different soil types; and (iii) assess farmers' perceptions of BP as a restoration method following bush control.

\section{Research method, design and study site}

\section{Application of BP as a restoration method}

A number of BT areas were identified by the DEFF in the Lephalale Municipality (including Shongoane village and the D'Nyala Nature Reserve (NR)) in the Limpopo Province and the Taung Municipality (which includes the Manthe village) in the North West province of South Africa. Shongoane and Manthe villages are communally managed lands affected by BT, and $\mathrm{D}^{\prime} \mathrm{Nyala} N R$ was a priority area for conservation and for controlling woody species (Figure 1). The Nature Reserve was selected as control, as protected, untransformed areas are known to be a good benchmark for biodiversity (Siebert et al. 2021).

The study sites at the Shongoane and Manthe villages were selected as suitable regions to also undertake the socio-economic surveys because the woody species causing BT (e.g. various Senegalia spp. and Vachellia spp., as well as Diospyros lycioides Desf. subsp. guerkei (Kuntze) De Winter and Dichrostachys cinerea (L.) Wight \& Arn. are highly abundant, and land users often have to abandon their land due BT and subsequent decrease in grazing capacity. The most prominent encroacher species on the communal lands in both Limpopo and North West province included thorn trees such as the umbrella thorn (Vachellia tortilis (Forssk.) Gallaso \& Banfi), black thorn (Senegalia mellifera (Vahl) Seigel \& Ebinger subsp. Detinens (Burch.) Kyal. \& Boatwr.) and sweet thorn (Vachellia karroo (Hayne) Banfi \& Glasso). The density and cover of these species could unfortunately not be determined before the trial. The camphor bush (Tarchonanthus camphoratus L.) also occurred in both areas and contributed to BT. All the study sites are classified as semi-arid, with rainfall averaging less than $430 \mathrm{~mm} /$ annum and temperatures ranging between 31 and $35^{\circ} \mathrm{C}$ during the warmest months (Engelbrecht \& Engelbrecht 2016). The majority of people in the communally managed communities are unemployed, with subsistence livestock husbandry and small-scale cropping being the dominant land uses. Around 400 people from local villages near Lephalale and at D'Nyala NR and 100 people from the Manthe village were employed to partake in bush clearing. 


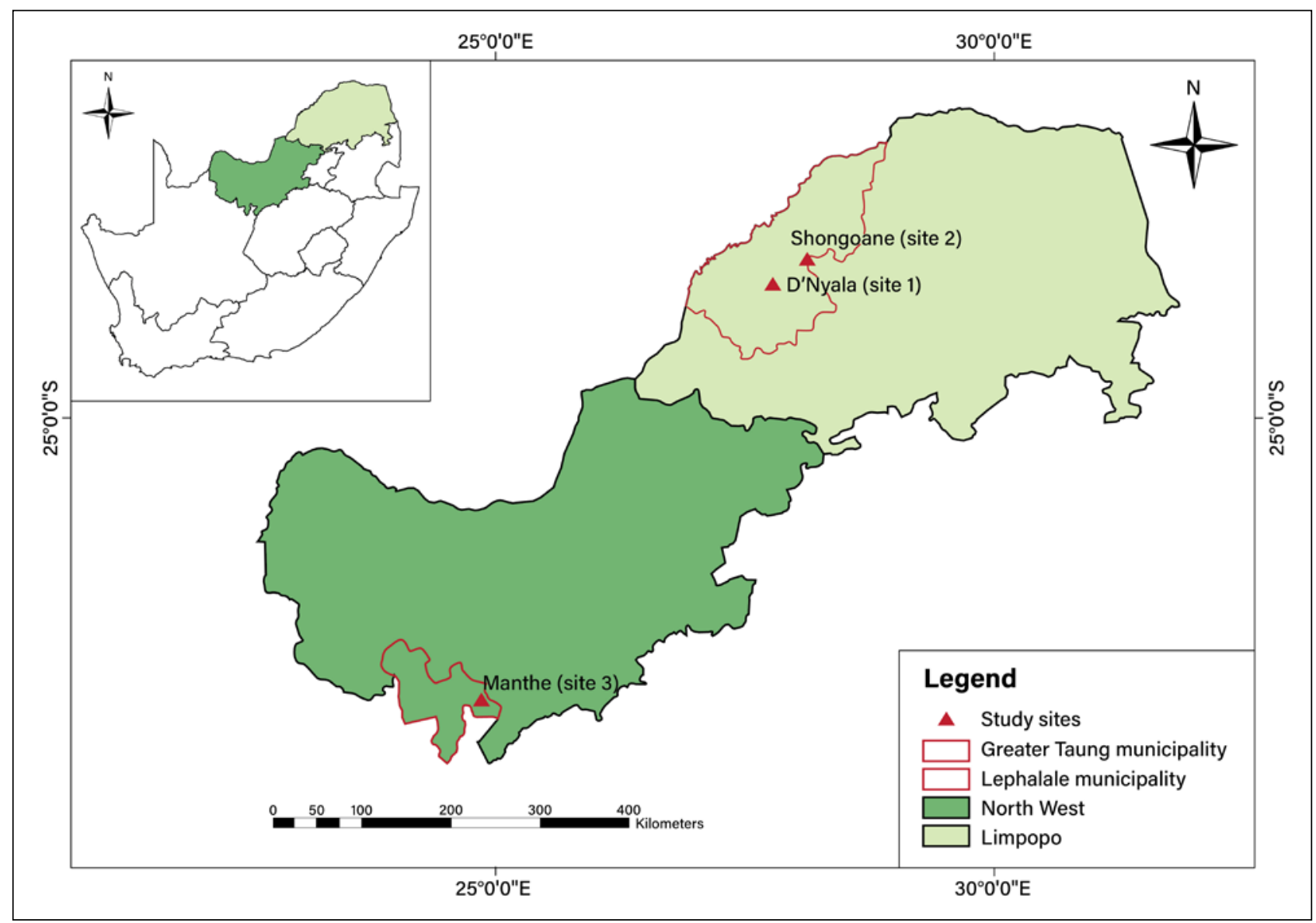

Figure 1. Location of the study sites in the Limpopo and North West provinces of South Africa. Manthe (Site 3) is in the North West, and D'Nyala NR (Site 1) and Shongoane (Site 2) in the Limpopo.

\section{Experimental layout and design}

The three study sites (D'Nyala NR, Shongoane and Manthe) had the same experimental designs. Six restoration experimental plots were constructed between September and November 2017 at each site (Figure 2). Each of the restoration plots were $400 \mathrm{~m}^{2}(20 \mathrm{~m} \times 20 \mathrm{~m})$ in size and arranged in a completely randomised block experimental design. Six different restoration methods were tested, replicated three times at each site. The treatments included different combinations of: (i) clearing, soil disturbance, brush packing and re-seeding (CSRSBP); (ii) clearing only-control (CO); (iii) clearing and brush packing (CBP); (iv) clearing and re-seeding (CRS); (v) clearing, brush packing and re-seeding (CRSBP); and (vi) no clearing/uncleared control (UC). At each of the three sites a total of 18 experimental plots were created (54 total) and half involved the BP method, which equalled almost half a hectare.

Woodies (shrubs and trees) of $3 \mathrm{~m}$ and less with a diameter of $10 \mathrm{~cm}$ at knee height were cleared using handsaws, clippers and a chain saw. After clearing/control, an arborocide (Kaput gel) that has the least impact on the environment was applied on the cut-stumps. Woodies taller than $3 \mathrm{~m}$ were considered as contributors for biodiversity, especially for the nesting of birds.
In Treatment 1 (Figure 2), the soil was lightly loosened with a rake (minimal soil disturbance) before re-seeding. A mixture of five annual and perennial grass species were used for the re-seeding of treatments 1,4 and 5, i.e. Cenchrus ciliaris L., Chloris gayana Kunth, Cynodon dactylon (L.) Pers., Digitaria eriantha Steud, and Eragrostis curvula (Schrad.) Nees. The seed of the grass species were mixed and broadcasted in the experimental plots $\left(200 \mathrm{~g} / 400 \mathrm{~m}^{2}\right)$. The grass species selected are native to and dominant in South African savannas. These grass species are a standard veld mixture used in conservation management (Van Oudtshoorn, 2012). For the BP restoration methods, branches of the cleared woody species at the sites were used. The same restoration and re-seeding methods were used at all the study sites (Figure 1).

\section{Measured variables}

\section{Biomass production}

After the trial was initiated in 2017, grass biomass was collected at the end of the 2018 and 2019 seasons. All grass was cut at a height of $5 \mathrm{~cm}$ above the ground in five randomly distributed $1 \mathrm{~m}^{2}$ quadrats per treatment and put in separate bags. During the growth season, no 


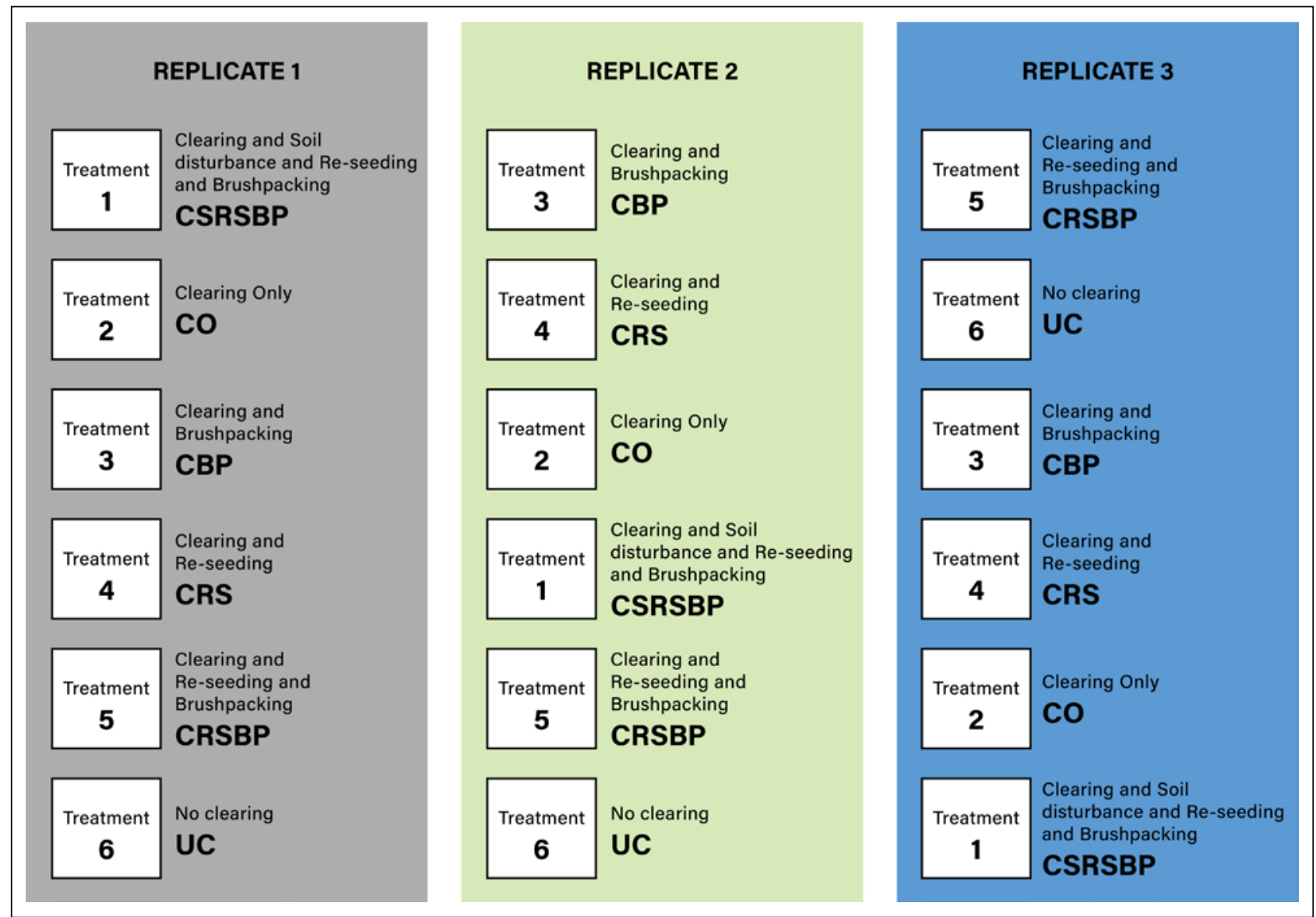

Figure 2. Experimental design and plot layout of the six restoration methods (treatments) in the three replicates in three blocks at each study site.

fertiliser was added to the soil and no irrigation applied. The grass samples in bags were oven dried at $67^{\circ} \mathrm{C}$ until constant weight and weighed to determine dry matter production.

\section{Grass species abundance/density}

Grass density was determined in the 2018 and 2019 seasons at each site in five $1 \mathrm{~m}^{2}$ quadrants of each experimental plot representing different restoration methods. Measurements were taken within the quadrant by counting the number of individual annual and perennial grass species appearing in the $1 \mathrm{~m}^{2}$ area. The total was added at the end of the five measured counts. Other herbaceous species were not included in these counts as this was not part of the research objective.

\section{Soil surveys}

Soil moisture is an important variable which affects infiltration, runoff, soil temperature and the amount of water available to plants. According to Gao et al. (2017), these variables are affected by BT due to the increase of high-density woody plant roots. Since soil moisture has a strong spatial-temporal variability and is affected by the soil type, moisture readings commenced at the end of 2019 rainy season (Gao et al. 2017). A neutron probe was used to measure soil water content at different depths at the three study sites (Manthe, Shongoane and D'Nyala NR) (Chanasyk \& Naeth 1996; Reichardt 2007). The soil moisture measurements were taken in the centre of one plot per treatment per site and totalling 18 (see Figure 2 above for the experimental design and layout).

The method of measuring soil moisture by means of the neutron probe entails that a hole is drilled into the soil using an auger followed by the installation of a tube (Reichardt 2007). The neutron probe was lowered into the soil in an access tube and readings were taken at different depths (Chanasyk \& Naeth 1996; Reichardt 2007). In this study, readings were taken at $10 \mathrm{~cm}$ intervals. A calibration equation was used to convert the thermal neutron count rate to soil moisture (Reichardt 2007). The equation used in this study was:

$$
y=0.3002 x-0.2158
$$

Where $y$ is the volumetric moisture content and $x$ is the thermal neutron count ratio.

Volumetric or concentration water content $(\mathrm{v} / \mathrm{v})$ is a measurement of soil moisture and is the ratio of water 
volume to soil volume and is represented by the following equation:

$$
\theta_{v}=\theta_{m} / D_{b} * 100
$$

Where $\Theta_{v}$ is the volumetric water content percentage, $\Theta_{m}$ is the volume of soil moisture and $D_{b}$ is the total soil.

For example, if volumetric soil moisture content is $\mathbf{1 3 . 1}$ $\mathrm{v} / \mathrm{v}$, then a volume of $13.1 \%$ of the total soil is soil moisture. Soil moisture contained in the soil pores or soil aggregates of the upper $10 \mathrm{~cm}$ of soil is called surface soil moisture. The upper $200 \mathrm{~cm}$ of soil moisture is named the root zone as most roots are found here although specialised species may penetrate deeper.

Soil texture and clay percentage were determined in the field by means of the 'hand texturing' method (Brown 2019). The method entails using a handful of moist soil followed by manipulating the soil into various shapes and judging the soil texture by the ability or coherence of the soil to remain in a certain shape (bolus, cylindrical and bent cylindrical shapes) (Brown 2019). Soil forms were determined using a 'Munsell Color Chart' (Munsell Color 1994) and Soil classification: a taxonomic system for South Africa (Soil Classification Working Group, 1991).

\section{Social and livelihoods survey (perceptions of land users)}

The perceptions on the socio-economic impact and land users' practices of the communal land users were assessed. The recruitment and participation process commenced in 2018. The first stage to initiate interest and participation was through the nduna/chief of the community. Thereafter, follow-ups were carried out through a mediator. Two different methods to gather data were used at the study sites. The quantitative, non-experimental, cross-sectional design was used at the Manthe study site (Mann 2003). A hundred randomly selected individuals (livestock owners and smallscale farmers) were interviewed at households in the village using semi-structured questionnaires where the $\mathrm{BP}$ project has benefited the community. Interviews were conducted in participants' own local language (Setswana). Questionnaires were used to provide quantitative data on the perceptions and socio-economic value of the environment.

At the Shongoane study site, a qualitative approach was used (Johnson \& Waterfield 2004). According to Moon et al. (2016) and Petty, Thompson and Stew (2012), qualitative research is defined by the nature of the questions asked in the research. The concept and methodologies were thus adopted during the design of the research, and the analysis and interpretation were associated with assumptions made when collecting the data (Khagram et al. 2010). Data was gathered through semi-structured interviews containing five questions. However, depending on the response given by the participant, a follow-up question was asked to gain a better understanding. The questions focused on the participant's general perception of the environment and the contribution made by the bush-clearing project since its inception. Data saturation was reached when no new information was discovered. Participants that were part of the sample consisted of a mixed group of males and females, ranging in age from 22 to 55. The interviews conducted with the participants were recorded.

\section{Statistical analysis}

The effect of the different treatments on biomass production was tested using a two-way analysis of variance (ANOVA). ANOVA was conducted using Genstat (Payne 2014). Multiple comparisons of means were performed using least significant difference (LSD) and Tukey's HSD range test. Tukey's test showed that only plots with BP treatment had an influence on grass biomass production $(p<0.05)$. Data from the two seasons were analysed separately because of significant $(p<0.05)$ season-year interactions.

The social study was analysed differently from the biophysical data. For the Shongoane survey the data were thematically analysed. A thematic analysis is a method commonly used in the analysis of qualitative data (Vaismoradi et al., 2013, Gibbs, 2007). The audio recordings obtained from the interviews at Shongoane were transcribed and analysed using thematic content analysis procedure, which included data coding, categorisation and thematic description and the identification of themes and sub-themes (Braun \& Clarke 2006; Gibbs 2007).

Basic statistically analysis and correlations for the quantitative social assessments were used for the surveys carried out at the Manthe study site (Field 2005).

\section{Ethical consideration}

As a primary requirement for social studies, the ethical clearance was awarded by the North-West University's Research Ethics Regulatory Committee. The ethical clearance numbers were PSB002-037-01-2018 and NWU-00120-18-A1 for the Manthe and Lephalale study sites respectively. Regulations of the university's registered ethics committee regarding research with human participants were considered during all phases of the study. 


\section{Results and discussion}

\section{Above-ground grass \\ biomass production}

The difference in the mean above-ground grass biomass production (g. $\mathrm{m}^{-2}$ ) during 2018 and 2019 at the three sites is illustrated in Figure 3 . There was a significant difference $(p<0.05)$ in grass biomass across the treatments at all sites. Two factors mainly influencing the grass biomass production were season and treatment (season-treatment interaction effect). From here on, the seasons will be considered separately to only consider the treatment effect.

The CO treatment at the Manthe site had the lowest grass production $\left(7.5 \mathrm{~g} . \mathrm{m}^{-2}\right)$ in the 2018 season. However, in the 2019 season, the lowest grass production $(21.8$ g.m$\left.{ }^{2}\right)$ was in the UC treatment at Manthe compared to the highest production of 296.4 g. $\mathrm{m}^{-2}$ in 2019 in the CSRSBP treatment. At Shongoane, the lowest grass biomass production (25.2 g. $\mathrm{m}^{-2}$ ) was in 2018 for the UC treatment, and in 2019 the treatment CRS produced the lowest grass biomass of $44.1 \mathrm{~g} \cdot \mathrm{m}^{-2}$ (Figure 3). At the $\mathrm{D}^{\prime}$ Nyala NR site, unlike the other sites where grazing animals were managed better, the lowest biomass was $28.2 \mathrm{~g} . \mathrm{m}^{-2}$ in 2018 for the CRS treatment, with only a $3 \mathrm{~g} \cdot \mathrm{m}^{-2}$ improvement in the 2019 season for the same treatment.

The highest produced biomass was obtained during the second season of monitoring (2019) within the CSRSBP treatment for the Manthe and Shongoane sites, which are communally managed lands, and the highest biomass production for the $\mathrm{D}^{\prime} \mathrm{Ny}$ ala NR site was produced for the CBP treatment in 2019. In the BP treatments the grass biomass production increased in the second season (Figure 3), with the highest increase at the Shongoane site (553.9 g. $\mathrm{m}^{-2}$ ), and also by 296.4 g. $\mathrm{m}^{-2}$ and $272 \mathrm{~g} . \mathrm{m}$ ${ }^{2}$ at the D'Nyala NR and Manthe sites respectively.

Biomass production increased with a notable effect in all brush packing treatments (CSRSBP, CBP and CRSBP). Generally, the CSRSBP, CBP and CRSBP produced a statistically similar grass biomass ( $p>0.05$ ), but all of them produced significantly higher biomass than the rest of the treatments $(p<0.05)$. The CBP treatment compared to the other BP treatments (CSRSBP and CRSBP) produced the highest grass biomass. With the high grass biomass production, grazing capacity and fodder production is improved (Ward 2005). Notably, a combination of re-seeding and brush packing did not yield higher grass production at any sites than expected. This could be because perennial grasses take longer to establish, and a two-season study does not show the effects immediately. Another reason is that the sites are in semi-arid regions, and the seeds could have dried in the ground before receiving enough moisture to germinate.

\section{Grass species abundance/ density in 2019}

The overall percentage of grass individuals (annuals, perennials and species richness) for the different restoration treatments at the three sites could be distinguished for 2019 (Table 1). The mean percentage of annuals were much higher at the Manthe site, whereas more perennials occurred at the Shongoane site (mean of $144.5 \%$ ) (Table 1). Annual species such as Aristida bipartita (Nees) Trin. \& Rupr., A. congesta Roem. \& Schult. subsp. congesta and Tragus berteronianus Schult. occur mostly in the UC and $\mathrm{CO}$ sites, and perennial species, such as $\mathrm{Cy}$ nodon dactylon (L.) Pers., Eragrostis trichophora Coss. \& Durieu, E. curvula (Schrad.) Nees and Microchloa caffra Nees. occurred in sites where BP was applied.

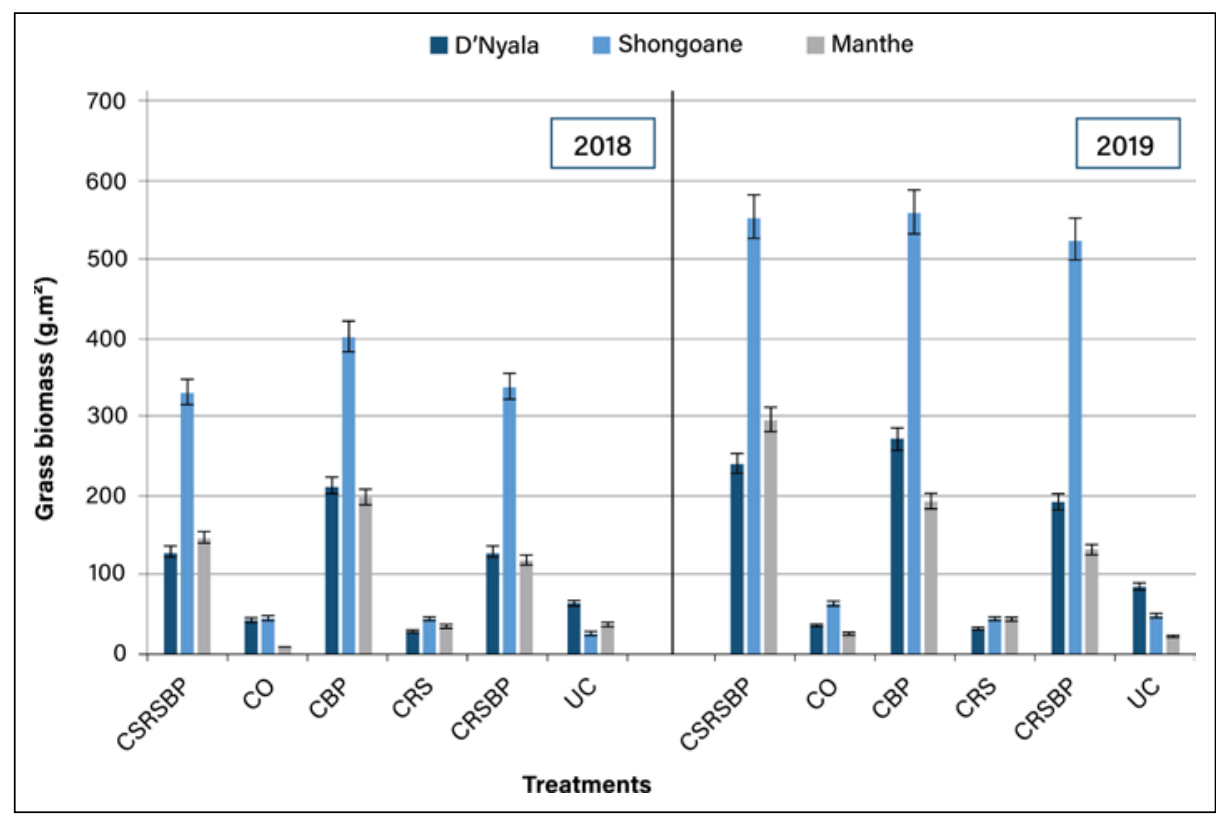

Figure 3: Above-ground grass biomass production (g.m-2) for the 2018 and 2019 seasons at the research sites D'Nyala NR, Shongoane and Manthe in different restoration treatments following bush clearing. Error bars indicate the 95\% confidence interval of each mean value.

Legend: Clearing and soil disturbance and brush packing and re-seeding (CSRSBP), Clearing only (CO), Clearing and brush packing (CBP), Clearing and re-seeding (CRS), Clearing and brush packing and re-seeding (CRSBP) and No clearing/ non-clearing (control plot) (UC) 
Table 1: Average grass abundance (\%) per $\mathrm{m}^{2}$ for annuals $(\mathrm{A})$ and perennials $(\mathrm{P})$, as well as total number of species per restoration treatment for 2019 at the Manthe, Shongoane and D'Nyala NR sites (see text for explanation of abbreviations for treatments)

\begin{tabular}{lcrrrrrrrr}
\hline Treatment & Manthe & \multicolumn{4}{c}{ Shongoane } & \multicolumn{3}{c}{ D'Nyala NR $^{\prime}$} \\
\cline { 2 - 10 } & $\mathbf{A}$ & $\mathbf{P}$ & Species richness & $\mathbf{A}$ & $\mathbf{P}$ & Species richness & $\mathbf{A}$ & $\mathbf{P}$ & Species richness \\
\cline { 2 - 10 } UC & 46 & 43 & 11 & 42 & 79 & 14 & 9 & 127 & 9 \\
\hline CO & 98 & 8 & 8 & 47 & 83 & 15 & 40 & 34 & 8 \\
CRS & 61 & 81 & 12 & 91 & 113 & 17 & 12 & 55 & 11 \\
\hline CBP & 74 & 43 & 10 & 21 & 183 & 16 & 34 & 87 & 14 \\
\hline CRSBP & 105 & 89 & 12 & 40 & 160 & 18 & 18 & 110 & 11 \\
\hline CSRSBP & 110 & 27 & 13 & 47 & 129 & 15 & 14 & 75 & 12 \\
\hline
\end{tabular}

The results revealed that BP restoration method contributed to higher perennial grass species abundance, especially at the Shongoane study site, which is characterised by high clay soils (Table 1). This suggests that brush packing's ability to increase rangeland grazing potential is dependent on soil type.

\section{Influence of BP restoration methods on soil moisture content in 2019}

The overall soil forms of Manthe, D'Nyala and Shongoane were: Mispah, Avalon and Rensburg, respectively. Mispah soils at Manthe had an average clay percentage of $38 \%$ in the A-horizon and $45 \%$ in the B-horizon. Mispah soil forms have a low water-holding capacity due to their shallowness. The soils at the study site of the D'Nyala NR consisted of 15\% (A-horizon) and 18\% (B-horizon) clay content respectively. The Avalon soil form is well drained and moderately slow to moderately permeable soils due to its depth and soil texture. The Rensburg soil studied at Shongoane indicated an A-horizon of more than $50 \%$ clay content, a B-horizon of more than $45 \%$ and a C-horizon of average $38 \%$. The Rensburg soil form of Shongoane exhibits deep swelling clays with high water holding capacity that increases with depth due to the swelling.

The volumetric soil moisture content was higher at deeper depths $(20-30 \mathrm{~cm})$ than in the shallower 0-10 cm surface soil for all study sites. The treatments that included BP illustrated higher moisture content differences with depth compared to non-brush packing treatments for $\mathrm{D}^{\prime} \mathrm{N}$ yala $\mathrm{NR}$, thus soils treated with BP contained more moisture (water) deeper into the soil profile than that of non-brush packing (Figure 4). Surface soil moisture $(0-10 \mathrm{~cm}$ of soil below the surface) values were also higher in treatments with BP than those without BP.

At the Manthe study site the soil surface moisture (0$10 \mathrm{~cm}$ ) content values illustrate no difference regarding the type of treatment. Manthe exhibited shallow (average $11 \mathrm{~cm}$ in depth) Mispah soils, containing rock fragments or gravel. During moisture measurements (February 2019) the maximum temperatures reached $32^{\circ} \mathrm{C}$ and no precipitation had occurred for a number of weeks, indicating that evapotranspiration had averaged the moisture content in the shallow soils. The UC (uncleared control) treatment indicated highest soil moisture content deeper into the soil profile (20$30 \mathrm{~cm}$ ) compared to the treatments.

At the Shongoane study site, the soil moisture had a greater (more than $100 \mathrm{v} / \mathrm{v}$ difference) moisture content difference between the surface soil $(0-10 \mathrm{~cm}) \mathrm{com}$ pared to deeper soil $(20-30 \mathrm{~cm})$, most likely due to an increase in clay content (swelling or expansive clay) with depth, compared to soils of D'Nyala NR and Manthe (Figure 4). No clear relationship was evident between treatment and soil moisture increase with depth. Overall soil moisture content of Shongoane was therefore higher with depth than the soil moisture of $\mathrm{D}^{\prime} \mathrm{Ny}-$ ala NR and Manthe, not due to the applied treatments, but due to soil type.

At the other two study sites ( $\mathrm{D}^{\prime}$ Nyala NR, Manthe) with higher sand content, soil moisture increased, but was not maintained with depth due to the leaching of water further into the soil profile. Shongoane site is comprised of a finer sand grade and higher clay content, which explains the increase in volumetric soil moisture content values. The first 10- $20 \mathrm{~cm}$ (A-horizon) consists of more than $48 \%$ clay, while the deeper B-horizon consists of more than $55 \%$ clay content. This phenomenon substantiates the increase of soil moisture with depth. D'Nyala exhibited the lowest amount of clay content and consisted of a fine to medium sand grade, which explicates the lower volumetric soil moisture values compared to that of the other sites. Wang et al. (2019) conducted a study on the effects of climate and vegetation on soil moisture on an arid area and concluded that precipitation, soil temperature and vegetation had influences on soil moisture variability. Soil temperature is expected to play a significant role in surface moisture content but was not part of this study based on site-specific limitations.

The rate of evaporation of moisture content in the surface soil $(0-10 \mathrm{~cm})$ is controlled by atmospheric conditions when the soil is sufficiently close to saturation (Brutsaert 2013). When surface soil is no longer sufficiently saturated, the effect of atmospheric conditions 
decreases and evaporation is controlled by the rate of water movement to the soil surface through the soil profile (Brutsaert 2013). Soil texture and vegetation affects water movement through soil pores in soils (leaching and capillary flow). The overall observation concluded that soil texture illustrates a strong affiliation with volumetric soil moisture content. A finer sand texture and higher clay content yielded higher volumetric soil moisture content values.

\section{Perceptions of local land users}

Most work examining the impact of woody encroachment or thickening on ecosystem services has focused on the biophysical and economic implications without examining land users' perceptions (Eldridge et al. 2011; Anadon et al. 2014). Insight into the land user's perceptions adds valuable information that will contribute to the importance of its application for future restoration projects to elevate the needs of the people living in these ecological systems.

At the Manthe study site, the majority of participating land-users were males (61.9\%) of whom only some had primary $(28.9 \%)$ or no formal education (17.5\%). Most participants (86.5\%) had a monthly household income of less than R2 000/month, with $46.9 \%$ relying on government grants and pensions as their main source of income. Nearly $62 \%$ of the participants keep livestock (mainly cattle and sheep) for financial security while the rest keeps livestock for food production (milk/meat).

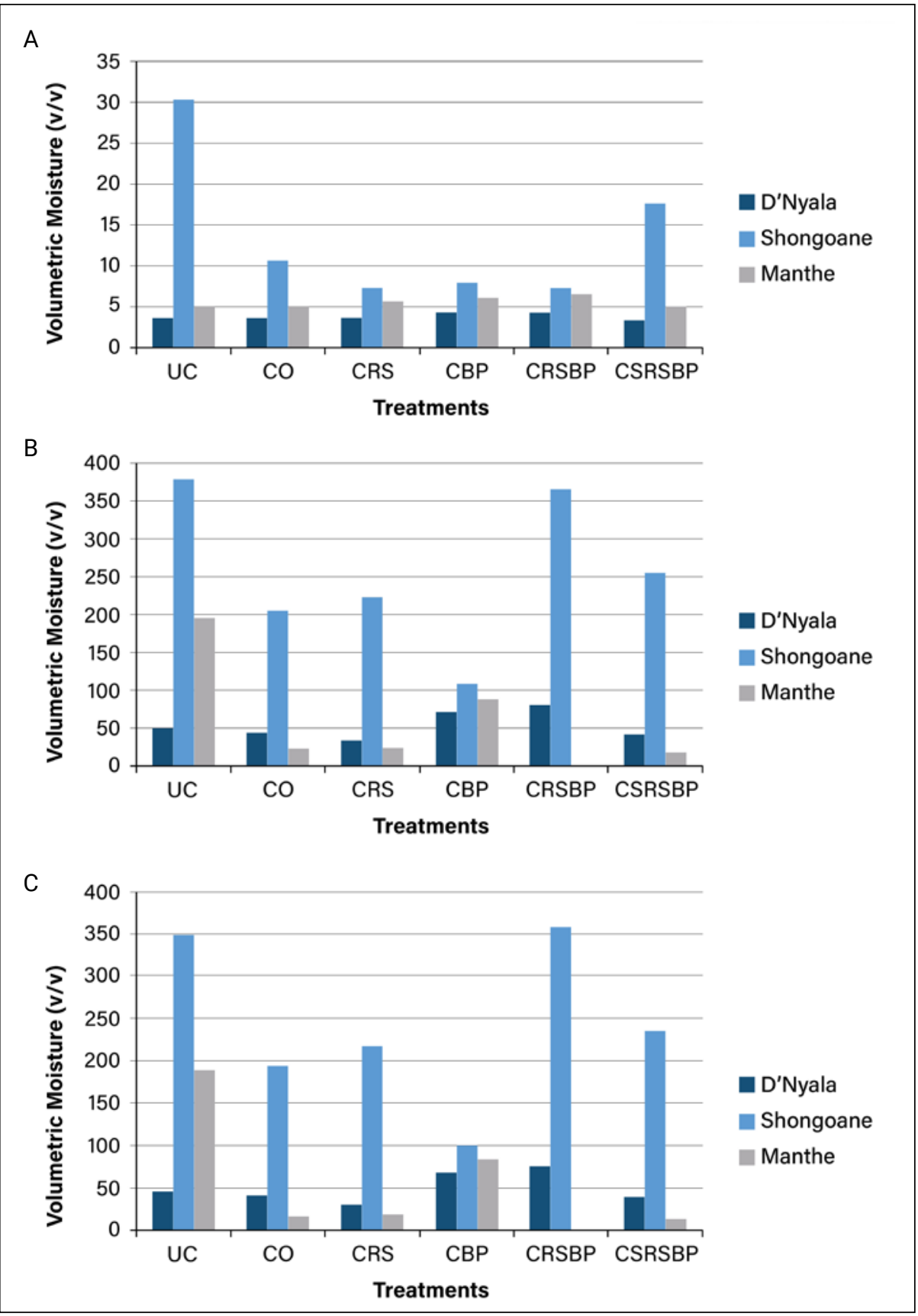

Figure 4. The volumetric soil moisture at two depths $(a: 0-10 \mathrm{~cm}$, b: $20-30 \mathrm{~cm}$ and c: the difference between the $10 \mathrm{~cm}$ and $20 \mathrm{~cm}$ depth in volumetric soil moisture) for the six restoration treatments at the three study sites for 2019 (Manthe, Shongoane and D'Nyala NR). 
In Limpopo (i.e. Shongoane village and the D'Nyala NR), a qualitative approach was used to gather data. The interviews conducted at Shongoane village and D'Nyala NR revealed that $65 \%$ of those directly involved in the bush-clearing project were women. From the interviews the following sub-themes emerged regarding bush clearing: employment opportunities; experience and training; and improved environmental conditions. The participants were of the opinion that the restoration programme offered employment, which enabled them to sustain their livelihoods. Furthermore, the programme offered an opportunity for community members, especially the previously unemployed, to be trained and to gain experience. The qualitative data revealed that participants' attitude towards the environment and its improvement is positively influenced by a project of this kind.

The overall impression of the participants about the restoration project to control $\mathrm{BT}$ was that it is beneficial to the community and should be maintained over the long term. The project not only inspired and encouraged participants, but residents of the Manthe and Shongoane villages at large took an interest and accepted responsibility for the restoration of the degraded rangelands and to gain an understanding of how this would improve their well-being. Imbursement of workers for clearing and implementing restoration treatments enabled them to buy groceries and clothes, and to take care of other basic needs. One participant from the Shongoane area even said that the remuneration contributed towards completing a building project. In terms of satisfaction with compensation for participation in the programme, women aged 25 years and above were more satisfied with the remuneration. Of interest here is that male participants in the age group 22-35 years complained that the remuneration they received was not sufficient to cover their needs in general.

Participants at the D'Nayala NR expressed that the project was beneficial since it provided employment and increased the livelihoods of the community surrounding the nature reserve. Eco-tourism also benefitted from the clearing/controlling of the dense woody species as it improved visibility in the nature reserve (De Klerk 2004; Arbieu et al. 2017).

\section{Conclusion}

The results showed that BP restoration treatments increased the grass biomass production over a two-year period. Increased grass biomass production will favour livestock owners and small-scale land users, especially in communally managed areas that are characterised by BT. The results show that the density of especially the perennial grasses improved in the plots where the BP restoration methods were applied especially in the Shongoane and D'Nyala sites. The grazing capacity should further improve over time if the BP restoration plots are maintained.
The volumetric soil moisture content was higher at deeper soil depths $(20-30 \mathrm{~cm})$ than in the shallower 0-10 cm surface soil for all study sites, but could not be linked to BP. This was especially evident at Shongoane and could be attributed to the higher clay content of the soils. The results show that, in the short term, soil type has a larger effect on the soil moisture content after restoration. More research over a longer time period is needed to determine if the soil moisture differences at the two depths sampled will occur due to BP, especially at the Shongoane and Manthe study sites.

The overall impression of the participants with regards to the restoration project to control BT was positive, as it did not only provide an income and increase in the grazing capacity for their livestock after restoration was carried out, but also made the people aware of land degradation and the value of their land. Participants at the $\mathrm{D}^{\prime}$ Nayala NR expressed that the restoration project was beneficial since it provided employment and increased the livelihoods of the community surrounding the nature reserve and also improved game viewing.

Participants showed appreciation for the cost-effective BP method especially after witnessing the positive results of grass biomass increase. The easy implementation of the BP methodology and the contribution to the well-being of the people was evident. It must be emphasised that only if this restoration method is maintained, will it have a positive impact on the SLM practices over the long term. Community members must therefore be encouraged to continue with the brush packing over larger areas seeing that it can help them increase the grazing capacity for the livestock in the region. Furthermore, since the implementation of effective BP methods can improve the livelihood of affected communities due to improved financial status, this method should be considered by both decision-makers and land users as a viable option to counter BE and BT.

\section{Acknowledgements}

The researchers at the North-West University want to acknowledge the participation of the communities at the different study sites who participated in the surveys, as well as the contractors of the Land User Incentive Programme of the Department of Environment, Forestry and Fisheries (DEFF) who helped with bush clearing/ control and brush packing. The DEFF is also thanked for financing the project.

\section{Authors contributions}

All the co-authors are thanked for their valuable contributions regarding the research and experiments carried out for the project, calculations after experiments and 
to write the manuscript. KK planned and coordinated the study, and wrote the manuscript in collaboration with HC, RM, TS and NM who collected field data and conducted data analyses, all from the North-West
University. JC helped with the supervision and statistical analysis (Agricultural Research Council). PM and JK, both from the North-West University, acted as co-supervisors for post-graduate studies.

\section{References}

Arbieu, U., Grünewald, C., Schleuning, M. \& Böhning-Gaese, K., 2017, 'The importance of vegetation density for tourists' wildlife viewing experience and satisfaction in African savannah ecosystems', PloS One, 12(9), 1-15, https://doi. org/10.1371/journal.pone.0185793

Barac, A., Kellner, K. \& De Klerk, N., 2004, 'Land user participation in developing a computerised decision support system for combating desertification', Environmental Monitoring and Assessment, 99(1-3), 223-231, https://doi. org/10.1007/s10661-004-4022-6

Britz, M.L. \& Ward, D., 2007, 'Dynamics of woody vegetation in a semi-arid savanna, with a focus on bush encroachment', African Journal of Range and Forage Science, 24(3), 131-140, https://doi.org/10.2989/AJRFS.2007.24.3.3.296

Brown, K., 2019, Soil texture. Measuring in the field [online]. Available at: http://soilquality.org.au/factsheets/soil-texture. (Accessed: 9 November 2019)

Braun, V. \& Clarke, V., 2006, 'Using thematic analysis in psychology', Qualitative Research in Psychology, 3(2), pp.77101.

Buitenwerf, R., Bond, W.J., Stevens, N. \& Trollope, W.S.W., 2012, 'Increased tree densities in South African savannas: $>50$ years of data suggests $\mathrm{CO}_{2}$ as a driver', Global Change Biology, 18(2), 675-684, https://doi.org/10.1111/j.13652486.2011.02561.x

Chanasyk, D.S. \& Naeth, M.A., 1996, 'Field measurement of soil moisture using neutron probes', Canadian Journal of Soil Science, 76(3), 317-323.

De Klerk, J.N., 2004, Bush encroachment in Namibia: Report on phase 1 of the bush encroachment research, monitoring, and management project, Windhoek: Ministry of Environment and Tourism, Directorate of Environmental Affairs, Namibia.

Donahue, A. \& Auburn, A.L., 2003, 'Soil compaction: Agronomy technical note', Effects of land management on soil quality, Soil Quality Institute, Noordstad, South Africa, pp.17:1-7.

Dreber, N., Van Rooyen, S.E. \& Kellner, K., 2018, 'Relationship of plant diversity and bush cover in rangelands of a semi-arid Kalahari savannah, South Africa', African Journal of Ecology, 56(1), 132-135, https://doi.org/10.1111/aje.12425

Eldridge, D.J., Bowker, M.A., Maestre, F.T., Roger, E., Reynolds, J.F. \& Whitford, W.G., 2011, 'Impacts of shrub encroachment on ecosystem structure and functioning: Towards a global synthesis', Ecology Letters, 14(7), 709-722, https://doi.org/10.1111/j.1461-0248.2011.01630.x

Engelbrecht, C.J. \& Engelbrecht, F.A., 2016, 'Shifts in Köppen-Geiger climate zones over southern Africa in relation to key global temperature goals', Theoretical and Applied Climatology, 123(1-2), 247-261, DOI: 10.1007/s00704014-1354-1

Field, A., 2005, Discovering statistics using SPSS (2nd ed.). London: Sage.
Gao, X., Zhao, X., Brocca, L., Huo, G., Ting, L. \& Wu, P., 2017, 'Depth scaling of soil moisture content from surface to profile: Multi-station testing of observation operators', Hydrology and Earth System Science Discussions, 12 July 2017, 1-25.

Gibbs, G.R., 2007, Thematic coding and categorizing' Analyzing qualitative data. London: Sage, pp. 38-56.

Gregory, A.S., Ritz, K., McGrath, S.P., Quinton, J.N., Goulding, K.W.T., Jones, R.J.A. et al., 2015, 'A review of the impacts of degradation threats on soil properties in the UK', Soil Use and Management, 31(Suppl. 1-15).

Harmse, C.J., Kellner, K. \& Dreber, N., 2016, 'Restoring productive rangelands: A comparative assessment of selective and non-selective chemical bush control in a semi-arid Kalahari savanna', Journal of Arid Environments, 135, 39-49.

Havstad, K.M., Peters, D.P., Skaggs, R., Brown, J., Bestelmeyer, B., Fredrickson, E. et al., 2007, 'Ecological services to and from rangelands of the United States', Ecological Economics, 64(2), 261-268, DOI: 10.1016/j.ecolecon.2006.12.001

Higgins, S.I., Bond, W.J., February, E.C., Bronn, A., Euston-Brown, D.I., Enslin, B. et al., 2007, 'Effects of four decades of fire manipulation on woody vegetation structure in savanna', Ecology, 88(5), 1119-1125, DOI: 10.1890/06-1664

Hoffman, M.T. \& Ashwell, A., 2001, Nature divided: Land degradation in South Africa. Cape Town: University of Cape Town Press.

Johnson, R. \& Waterfield, J., 2004, 'Making words count: The value of qualitative research', Physiotherapy Research International, 9(3), 121-131, doi: 10.1002/pri.312.

Joubert, D.F., Rothauge, A. \& Smit, G.N., 2008, 'A conceptual model of vegetation dynamics in the semi-arid Highland savanna of Namibia, with particular reference to bush thickening by Acacia mellifera', Journal of Arid Environments, 72(12), 2201-2210, DOI: 10.1016/j. jaridenv.2008.07.004

Kellner, K., 2008, Studies in land degradation, desertification and restoration ecology: Challenges and opportunities, Potchefstroom: North-West University Press.

Kellner, K., Von Maltitz, G., Seely, M., Atlhopheng, J \& Lindeque, L., 2018, 'South African arid lands: current status and future prospects' in Guar, M.K. \& Squires, V.R. (eds) Climate variability impacts on land use and livelihoods in drylands. Cham: Springer, pp. 243-260.

Kgosikoma, O.E., Harvie, B.A. \& Mojeremane, W., 2012, 'Bush encroachment in relation to rangeland management systems and environmental conditions in Kalahari ecosystem of Botswana', African Journal of Agricultural Research, 7(15), 2312-2319, DOI: 10.5897/AJAR11.2374

Khagram, S., Nicholas, K.A., Bever, D.M., Warren, J., Richards, E.H., \& Oleson, K., 2010, 'Thinking about knowing: Conceptual foundations for interdisciplinary environmen- 
tal research', Environmental Conservation, 37(4), 388-397, https://doi.org/10.1017/S0376892910000809

Kraaij, T. \& Ward, D., 2006, 'Effects of rain, nitrogen, fire and grazing on tree recruitment and early survival in bush-encroached savanna, South Africa', Plant Ecology, 186(2), 235-246, https://doi.org/10.1007/s11258-006-9125-4

Liniger, H.P. \& Mekdaschi Studer, R., 2019, Sustainable Rangeland Management in Sub-Saharan Africa - Guidelines to good practice. Bern: Centre for Development and Environment (CDE), University of Bern.

Lukomska, N., Quaas, M.F. \& Baumgärtner, S., 2014, 'Bush encroachment control and risk management in semi-arid rangelands', Journal of Environmental Management, 145(1), 24-34, DOI: 10.1016/j.jenvman.2014.06.005

Mann, C.J., 2003, 'Observational research methods. Research design II: Cohort, cross sectional, and case-control studies', Emergency Medicine Journal, 20(1), 54-60, http:// dx.doi.org/10.1136/emj.20.1.54

Modungwa, R.T., 2017, 'The effect of brush packing on soil surface conditions that influence grass emergence and establishment on denuded soils', MSc dissertation. University of Pretoria, Pretoria. Available at: http://hdl.handle. net/2263/61272 (Accessed: 16 September 2019).

Moon, K., Brewer, T., Januchowski-Hartley, S., Adams, V. \& Blackman, D., 2016, 'A guideline to improve qualitative social science publishing in ecology and conservation journals', Ecology and Society, 21(3), 17, http://dx.doi. org/10.5751/ES-08663-210317

Mucina, L. \& Rutherford, M.C., 2006, The vegetation of South Africa, Lesotho and Swaziland, Pretoria: South African National Biodiversity Institute.

Munsell Color, 1994, Munsell Soil Color Charts, 1994 revised edition. New York: Macbeth Division of Kollmorgen Instruments Corporation, New Windsor.

Mulder, J. \& Brent, A.C., 2006, 'Selection of sustainable rural agriculture projects in South Africa: Case studies in the LandCare programme', Journal of Sustainable Agriculture, 28(2), 55-84, https://doi.org/10.1300/J064v28n02_06

Payne, R.W. (ed.), 2014, Introduction to GenStat ${ }^{\circledR}$ for Windows $^{\text {TM }}$ (17th ed.), Available at: http://www.genstat.co.uk/ (Accessed: 22 September 2017).

Petri, M., Biancalani, R. \& Lindeque, L., 2019, Guidelines for the national assessment and mapping of land degradation and conservation. Available at: http://www.fao.org/3/ ca3999en/ca3999en.pdf (Accessed: 2019).

Petty, N.J., Thomson, O.P. \& Stew, G., 2012, 'Ready for a paradigm shift? Part 1: Introducing the philosophy of qualitative research', Manual Therapy, 17 (4), 267-274, doi: 10.1016/j.math.2012.03.006

Reichardt, K., 2007, Measurement of soil water, use of neutron probe and tensiometers 2. Trieste: The Abdus Salam International Centre for Theoretical Physics.

Rothauge, A. \& Gschewender, F., 2014, Baseline assessment for the de-bushing programme in Namibia, Windhoek: Deutsche Gesellschaft für Internationale Zusammenarbeit.

Schwilch, G. Hessel, R. \& Verzandvoort, S., 2012, Desire for greener land. Options for sustainable land management in drylands. Bern: University of Bern.

Shackleton, C., Shackleton, S., Gambiza, J., Nel, E., Rowntree, K. \& Urquhart, P., 2008, Links between ecosystem services and poverty alleviation: situation analysis for arid and semi-arid lands in southern Africa, Cape Town: Consortium on Ecosystems and Poverty in Sub-Saharan Africa. Available at: http://www.unpei.org/PDF/preliminaryassessments/Links-Ecosystem-Services-and-Poverty-Alleviation. pdf (Accessed: 15 February 2013).

Siebert, F., Van Staden, N., Kompane, D.M., Schwemmer, A.M. \& Siebert, S.J., 2021, 'Effects of land-use change on herbaceous vegetation in a semi-arid Mopaneveld savanna', Bothalia 51(1): 107-132 (hardcopy); 1-26 (online) [this issue].

Skowno, A.L., Thompson, M.W., Hiestermann, J., Ripley, B., West, A.G. \& Bond, W.J., 2017, 'Woodland expansion in South African grassy biomes based on satellite observations (1990-2013): General patterns and potential drivers', Global Change Biology, 23 (6), 2358-2369, https:// doi.org/10.1111/gcb.13529

Smit, G.N., Richter, C.G.F. \& Aucamp, A.J., 1999, 'Bush encroachment: An approach to understanding and managing the problem' in NM. Tainton (ed.), Veld management in South Africa. Pietermaritzburg: University of Natal Press, pp. 246-260.

Society for Ecological Restoration, Science and Policy Working Group, 2004, The SER primer on ecological restoration. Available at:: http://www.ser.org/ (Accessed: 20 June 2019).

Soil Classification Working Group, 1991, Soil classification - a taxonomic system for South Africa, Memoirs on the Agricultural Natural Resources of South Africa No. 15. Pretoria: Department of Agricultural Development.

South African National Department of Agriculture (NDA), 2005, LandCare South Africa., Available at: http://www. nda.agric.za/docs/Landcarepage/landcare.htm (Accessed: 20 June 2019).

Sudha, P., Somashekhar, H.I., Rao, S. \& Ravindranath, N.H., 2003, 'Sustainable biomass production for energy in India', Biomass and Bioenergy, 25 (5), 501-515, DOI: 10.1016/ S0961-9534(03)00087-4

Swift, M.J., Izac, A.M.N. \& Van Noordwijk, M., 2004, 'Biodiversity and ecosystem services in agricultural landscapes - Are we asking the right questions?', Agriculture, Ecosystems \& Environment, 104(1), 113-134, DOI: 10.1016/j. agee.2004.01.013

Tongway, D.J. \& Ludwig, J.A., 2011, Restoring disturbed landscapes: Putting principles into practice, Washington: Island Press.

Turpie, J., Botha, P., Coldrey, K., Forsythe, K., Knowles, T., Letley, G., Allen, J. \& de Wet, R., 2018, Towards a policy on indigenous bush encroachment in South Africa, Pretoria: Department of Environmental Affairs.

Van Oudtshoorn, F., 2012, Guide to grasses in South Africa, Cape Town: Briza.

Van Wilgen, B.W., Richardson, D.M., Le Maitre, D.C., Marais, C. \& Magadlela, D., 2001, 'The economic consequences of alien plant invasions: Examples of impacts and approaches to sustainable management in South Africa', Environment, Development and Sustainability, 3 (2), 145-168, https:// doi.org/10.1023/A:1011668417953

Vaismoradi, M., Turunen, H. \& Bondas, T., 2013, 'Content analysis and thematic analysis: Implications for conducting a qualitative descriptive study', Nursing \& Health Sciences, 15 (3), 398-405, doi: 10.1111/nhs.12048 
Visser, N., Morris, C., Hardy, M.B. \& Botha, J.C., 2007, 'Restoring bare patches in the Nama-Karoo of South Africa', African Journal of Range and Forage Science, 24 (2), 87-96, https://doi.org/10.2989/AJRFS.2007.24.2.5.159.

Von Maltitz, G.P., Lindeque, G.H.L. \& Kellner, K., 2018, 'A changing narrative on desertification and degradation in South Africa', in Victor Roy Squires \& K. Gaur (eds.), Desertification, New York: Nova Science Publishers, pp. 39-98.

Von Maltitz, G., Gambizo, J., Kellner, K., Rambau, T., Lindeque, L., Kgope, B., 2019, 'Experiences from the South
African land degradation neutrality target setting process', Environmental Science \& Policy, 101, 54-62.

Ward, D., 2005, 'Do we understand the causes of bush encroachment in African savannas?' African Journal of Range and Forage Science, 22(2), 101-105, https://doi. org/10.2989/10220110509485867.

Wigley, B.J., Bond, W.J. \& Hoffman, M.T., 2009, 'Bush encroachment under three contrasting land-use practices in a mesic South African savanna', African Journal of Ecology, 47 (1), 62-70, https://doi.org/10.1111/j.13652028.2008.01051.x 